\title{
An Evaluation of Training Needs of the Nigerian Construction Professionals in Adopting Building Information Modelling
}

\author{
Oyewole Oluwatosin Elijah and *Dada Joshua Oluwasuji
}

\begin{abstract}
Published online: 31 December 2019
To cite this article: Oyewole Oluwatosin Elijah and Dada Joshua Oluwasuji (2019). An evaluation of training needs of the Nigerian construction professionals in adopting Building Information Modelling. Journal of Construction in Developing Countries, 24(2): 63-81. https://doi.org/10.21315/jcdc2019.24.2.3.
\end{abstract}

To link to this article: https://doi.org/10.21315/jcdc2019.24.2.3

\begin{abstract}
The use of Building Information Modelling (BIM), for construction processes, is on the increase across the globe. This paper aims at exploring the training needs of the Nigerian construction professionals in the adoption of BIM. The study was carried out through a qualitative research design and a structure questionnaire survey administered on selected construction professionals in Nigeria. A total of 285 questionnaires were distributed among the sampled respondents out of which a total of 212 (74.39\%) valid responses were received. The data generated were analysed using descriptive and inferential statistics. The results revealed computing skill, cost modelling skill, computer aided design skill, construction technology skill, coordination skill as the most essential skills required for the adoption of BIM. On training method appropriate for BIM adoption, the results showed that organising regular workshop and attending related conferences on BIM, on job training/project-based training, including BIM training in firm's syllabus and hiring a BIM specialist for staff training as the most significant. Furthermore, internet connectivity, integrated computer systems and availability of BIM software were significant facility requirements in adopting BIM. The study provides information on the actual training needs and facilities required as potential for BIM adoption among construction professionals in Nigeria.
\end{abstract}

Keywords: Building Information Modelling, Construction professionals, Facilities, Skills, Training needs

\section{INTRODUCTION}

The issue of training and re-training cannot be overemphasised in any human field of endeavour. This is particularly keen in professional related firms and organisations. It is seen as a critical and challenging task that has come to be identified with the determination of the future of many organisations. In the absence of continuous, relevant and appropriate training, employees of an organisation may fail to perform at the level expected of them and in the process leading to the collapse of businesses (Ondari-Okemwa, 2000). Au, Altman and Roussel (2008) posited staff or employee as the only resource a firm has that cannot be reproduced and indeed that provide the principal source of a firm's competitive advantage. Employees training is seen as vital and therefore become an essential element to organisational success (Carlisle, Bhanugopan and Fish, 2011). Due to the current exponential growth in technology and its effects on the economy and the society at large, the need for training has become more evident than ever (Alkinani, 2013). In this regard, Underwood and Ayoade (2015) advocated for adequate training of construction 
professionals, in relevant technologies, for reduction in capital expenditure. One of such technology is Building Information Modelling (BIM). BIM has been described as an emerging technological breakthrough and revolutionary technology capable of facilitating collaboration, increasing productivity and efficiency of design and construction processes through innovative modelling software (Rogers, Chong and Preece, 2015; Whitlock et al., 2018). It is being used in the management of construction project with the specific potential of improving coordination, communication, data management, analysis, simulation, construction productivity and facilities management (McGraw Hill, 2009). It also serves as integrating platform for the fragmented architectural, engineering and construction (AEC) industry and thereby optimising stakeholders' performance. According to Enegbuma et al. (2016) BIM presents ample advantages for construction professionals who invariably lead to improvements in efficiency and client satisfaction. The opportunities that BIM presents warrant an enhancement to the existing set of skills and knowledge of the construction professionals. On this premise, the general findings of researches carried out on BIM application to construction processes (Kraatz, Sanchez and Hampson, 2014; Zhang, Seet and Lie, 2015) signalled training and skilling as significant factors impacting BIM uptake. Whereas, high rate of BIM adoption is globally more visible in the developed economies where research activity focusing on BIM has also increased (Ibrahim and Abdullahi, 2016), the story in the developing countries, such as Nigeria, is quite opposite. Onungwa and Uduma-Olugu (2017) attributed this problem to the inability of Nigerian construction professionals to keep pace with the modern advancement in technology. In light of this, there is need for effective training in maximising the ever-advancing technology and on this basis; this study explores the requisite training needs of the Nigerian construction professionals in adopting BIM. The paper commenced with a review of relevant literature which was followed by a description of the research method and presentation of the research findings. The main findings are discussed and conclusions drawn with appropriate recommendations.

\section{Theoretical Concept}

Training has longtime been identified as one of the fundamental and significant processes within the construction industry which can assist organisations/firms meet the needs of construction professionals (Odusami, Oyediran and Oseni, 2007). The authors emphasised the need for employees' continuous training without which many will become obsolete and irrelevant. Hassan, Griffith and Stephenson (2005) posited that training is associated with the performance of people in their job and performance gaps implying that there is a shortfall in the knowledge and skills capacity in undertaking expected roles or task. There is therefore the need for developing a Training Need Analysis (TNA) which is a vital part of training design process that attempts to reduce knowledge and performance gap by finding out what needs to be taught (Hassan et al., 2005, Detsimas et al., 2016). In this regard Peña-mora, Vadhavkar and Aziz (2009) and Plume and Mitchell (2007) emphasised the need for construction, engineering and management educator to inculcate fundamentals related to information technology concepts in AEC curriculum. In doing this, effort must be on courses that provide sufficient integration of multidisciplinary and practice-based topics rather than only on technical courses (Becerik-Gerber, Gerber and Ku, 2011). Also, in order to highlight the trends, advances and gaps in research on BIM education in AEC curricula, 
Abdirad and Dossick (2016) conducted a systematic literature review on BIM. Specifically, the authors extracted and analysed existing BIM knowledge and developed a framework on curriculum design issues, which served as basis for synthesising findings on BIM curriculum design strategies. In addition, Becerik-Gerber, Ku and Jazizadeh (2012) advocated for focus on modes of learning which involve virtual collaboration, problem-oriented project-based learning and role-based learning with a view to combining experimental and experiential learning experience. In light if this, Bernstein and Pittman (2011) opined that the implementation of BIM requires devising a well-thought-out plan that addresses the business and process issues, as well as software, pilot projects, software training and rollout. Furthermore, the research carried out by Kraatz et al. (2014) signalled training and skilling as the critical factors influencing the adoption of BIM in Australian construction industry. Tulenheimo's (2015) study also emphasised the need to give due consideration to different aspects of BIM requirements for its successful implementation. These and other research efforts regarding BIM adoption is pointing attention to adequate training as a panacea for BIM implementation. Therefore, the issue of training is seen as very key and remain a research agenda for full implementation of BIM.

\section{BIM Concepts and Application to Construction Process}

In a complex and dynamic industry environment the role played by the various professions is likely to fluctuate and change. New techniques may make some traditional roles obsolete and others may be greatly altered in scope and responsibilities (Hardie et al., 2005). Brummer (2004) showed that trends in the construction industry are continuously changing and innovative procurement systems are part of the reality of future services. BIM is one of the innovative practices which have become a better known established collaboration process in the construction industry (Kulasekara, Jayasena and Ranadewa, 2013). The need to increase sustainability and productivity within the construction industry has led to the advent of BIM (Niraj and Dan, 2013). BIM in its collaborative way of working underpinned digital technologies which unlock more efficient methods of designing, creating and maintaining assets (Aftab et al., 2014). It allows for collaboration in design at the early stage of a project. Usually, this enables consultants to take their decisions at a project's early stage and reduce changes that may occur at a later stage in the design process (Onungwa and Uduma-Olugu, 2017).

BIM, according to Davidson (2013), is not just a tool; it is a collection of tools and processes resulting in a product that is greater than the sum of its part. Hosseini et al. (2014), Rogers et al. (2015) and Puolitaival and Forsythe (2016) described it as an agglomeration of processes that is rapidly transforming the construction industry for best practice, performance and improved project delivery; and vast becoming a common technology used in management of construction projects. It permits for a digital representation of a structure to be created which implies that building components such as columns, beams, doors and windows are elements digitally represented by the Building Model. In this regard, Singh, Sawhney and Sharma (2017) particularly utilised the concept of BIM data for formwork quantification, visualisation, scheduling, clash resolution and resource planning. Travaglini, Raduckovic and Mancini (2014) described BIM as a socio-technical system which shows the combination of man-made technology and the social and institutional consequences of its implementation in the society. It is made of associated behaviours, social norms, definite relationships and cultural institutions which 
require acquisition of knowledge through adequate training. Meanwhile, Zhang et al. (2015) describe BIM as a method enabled by a set of software tools and processes for facilitating the creation and use of the digital representation of the physical and functional characteristics of a facility. Accordingly, BIM can be regarded as one efficient technique used to improve the capabilities of construction professionals and the innovative change that the construction industry expects to adopt in eliminating wastage, cost overruns, mismanagement and disputes.

\section{Antecedents of BIM Training}

BIM tools bear significant potential to enhance the integrated project delivery, as well as to accelerate its implementation in practice (Fellows and Liu, 2010). The tools offer adequate support for interdisciplinary planning, design, data exchange and management along the life cycle of a building (Penttila, 2006). Succar (2009) and Dim, Ezeabasili and Okoro (2015) categorised BIM software available for construction professionals according to their professional practice in the construction industry. The BIM tools categories are tabulated in Table 1. These BIM tools and software are essentials in training construction professionals in adopting BIM. Adequate knowledge of the use of BIM tools will enhance the knowledge competence of construction professionals in the industry. Meanwhile, Aftab et al. (2014) enlisted 12 skill requirements for the adoption of BIM concepts and applications in the construction industry (as shown in Table 2).

Table 1. Training Needs for BIM Tools

\begin{tabular}{ll}
\hline Training Needs for BIM Tools & BIM Software \\
\hline Planning tools & Bentley Arch, AutoCAD \\
Design tools & ArchiCAD, AutoCAD, Graphisoft Archicad \\
Virtual modelling tools & Autodesk Revit, Autodesk, Bentley Systems \\
Procurement tools & QS Plus, VICO \\
Fabrication tools & CADDUCT, FireCAD \\
Scheduling and sequencing tools & MS Project, Solibri Model Checker \\
Estimating tools & QS Plus, MicroStation \\
Construction tools & Nemetschek Vectorworks, TEKLA, Naviswork, \\
Facility maintenance tools & Synchro Project Constructor \\
\hline
\end{tabular}

Source: Succar (2009) and Dim, Ezeabasili and Okoro (2015)

Odusami et al. (2007) opined that training methods are the fundamental catalysts and stimulators for leaning. Training methods in most developing countries are referred to as training techniques or training methodologies. Suitable training methods required for the adoption of BIM depends on the job method, off the job method, in-house, out of house, over the shoulder, formal classes, luncheon roundtables, project-based, web-based and etc. Construction professionals and 
their firms need to train well, train often and train continuously (Bernstein and Pittman, 2011 ). The suggested training methods suitable for the adoption of BIM are presented in Table 3.

Table 2. Skill Requirements for BIM Adoption

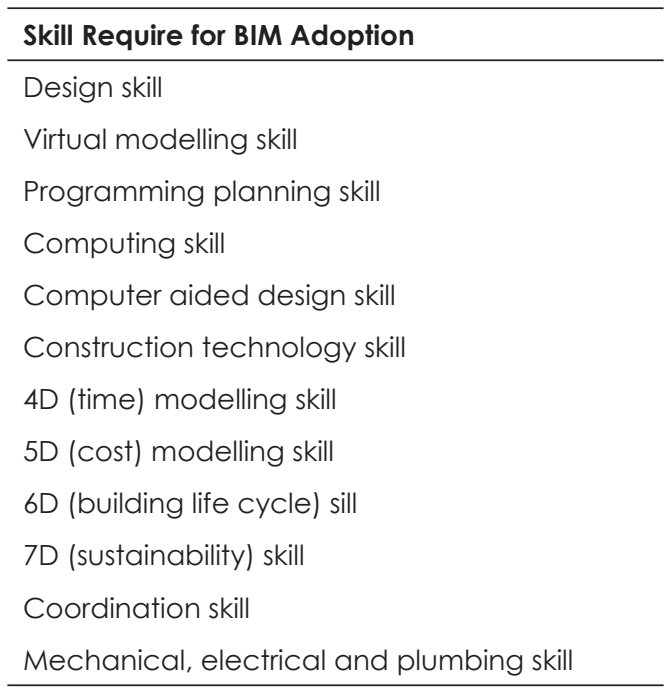

Source: Aftab et al. (2014)

Table 3. Training Methods Suitable for BIM Adoption

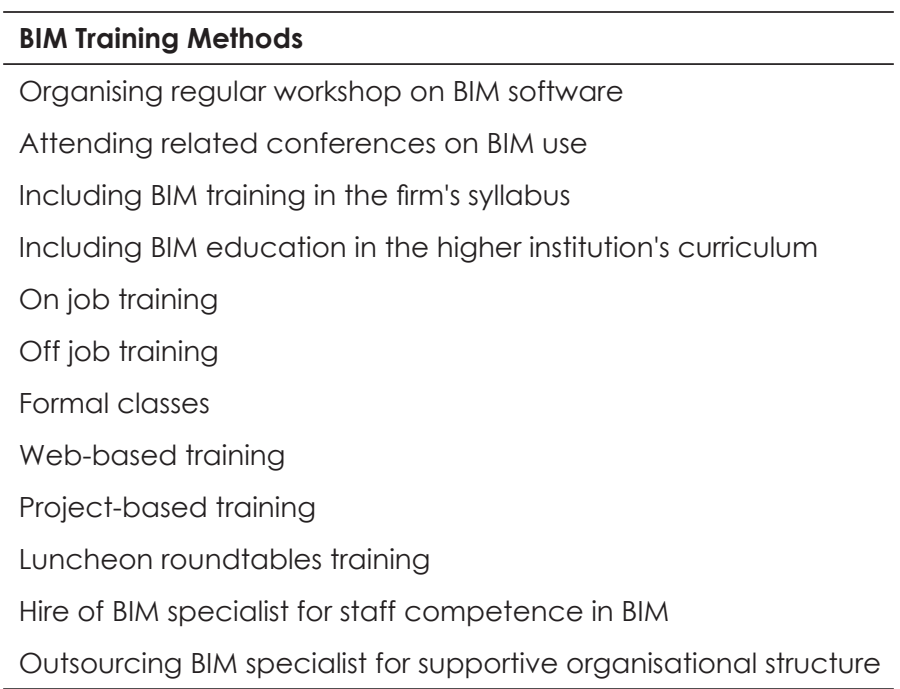

Source: Oke (2016), Jupp (2015) and Bernstein and Pittman (2011) 
Regarding facilities required for BIM training and adoption, firms typically require hardware and networking upgrades such as more powerful central processing units (CPUs), large memory and data storage device, wide area network (WAN) devices and large screen monitors, communication devices, etc. Technology training needs for efficient BIM operations is based on technology for collaboration through the use of video conferencing technology and large display screens (Jupp, 2015). To enhance technology for analysis and visualisation, visualisation software can be used to advance design. To enhance the sheer amount of information shared, a data management solution through the use of additional computing power such as cloud computing (McGraw Hill, 2009). Successful adoption of BIM concepts and applications demand for adequate training on BIM enabled tools, skill requirements and BIM software. The use of appropriate training methods and provision of facilities can easily enhance training of construction professionals in the adoption of BIM.

\section{An Overview of BIM Adoption in Africa}

Studies have revealed that BIM adoption is rapidly expanding around the globe. Jung and Lee (2015) found that the more advanced a country is, the more number of BIM services employed in general. Accordingly, North America, Europe, Oceania and Asia were found to be advancing rapidly toward the mature stage of BIM, whereas the Middle East/Africa and South America were found to still be in the early phase. Further review in most developing African countries shows that BIM adoption is still very low. For example, the studies by Ede (2014), Olugboyega (2016), Olugboyega and Aina (2016) and Onungwa and Uduma-Olugu (2017) indicated that BIM adoption on Nigeria is still in its infancy within the industry and that the spectrum of BIM usage has not been fully utilised. Ogwueleka and Ikediashi (2017) described the situation of BIM skill acquisition in Nigeria as abysmally low, with the various consultants reluctant in putting up extra efforts on creating BIM platforms. Froise (2014) indicated that South Africa first embraced the BIM technology in the AEC sector during construction activities for FIFA 2010 World Cup. Though it has since then received its fame, however, several challenges are confronting its implementation. One of such factor was identified as lack of knowledge and capability of the various stakeholders. In the same vein, Kekana, Aigbavboa and Thwala's (2014) study revealed one of the major barriers to the adoption and implementation of BIM as personnel inadequacies in terms of education, training and skills development. The study by Abanda et al. (2014) indicated that some BIM software are already being used in Cameroon, but the major barriers hindering BIM uptake was identified as high license fee and lack of huge projects that can pay off the cost of investment in BIM. In Libya, the study carried by Sheglabo, McGill and Dixon (2017) on factors that impact the intention to adopt and use mobile information communication technology (mlCT) found that the intention to adopt and use $\mathrm{mICT}$ in the Libyan construction industry was directly affected by perceived usefulness of $\mathrm{mICT}$ and indirectly affected by perceived $\mathrm{mICT}$ self-efficacy and facilitating conditions. Meaning that, the more stakeholders perceive mICT useful as and easy to use, the more likely they are to intend to adopt and use it. Generally, several other researches have highlighted factors limiting or inhibiting BIM adoption in the construction industry and cardinal of such was identified by the Royal Institute of Chartered Surveyors (RICS) (2015) as lack of education and training. 


\section{Challenge of BIM Training and Uptake among Nigerian Construction Professionals}

The studies of Olugboyega (2016), Olugboyega and Aina (2016) and Onungwa and Uduma-Olugu (2017) clearly indicate that efforts at adopting BIM, amongst Nigerian construction professionals, have been very slow. Though the Nigerian architects have adopted BIM (Dare-Abel, Igwe and Charles, 2014), but this has been used mainly for enhancing visual quality presentation (Alufohai, 2012; Ibrahim, Abubakar and Osunkunle, 2015). Also, Kori and Kiviniemi (2015) found that architectural firms in Nigeria use BIM as a mere technology transformation without any accompanying benefits due to lack of the understanding of the use for collaboration and integration purposes. Meanwhile, other professionals continue to produce their drawings with two-dimensional (2D) AutoCAD and in view of this, collaboration on BIM-based projects is not effective. Dim, Ezeabasili and Okoro (2015) berated the continuous working and reliance of Nigerian construction professionals on 2D and threedimensional (3D) technologies and yet hope to catch up with the full value that BIM brings to project implementation. However, the full application of BIM cannot be appreciated until the factors influencing its adoption have been investigated.

Oladapo (2006) and Abubakar et al. (2014) pinpointed lack of skilled personnel as a major barrier of BIM adoption in Nigeria. Another key barrier is the interoperability risks between different programs used in construction processes (Azhar, Khalfan and Maqsood, 2012). In this regard, it can be seen that training is very key in adopting BIM. Most of the professionals have to result to training themselves or learn on the job. Hassan and Yolles (2009) identified "fear of change" as barrier to adopting BIM. Most people are comfortable with the software they use and, as a result, find it difficult to change or switch to another one. In overcoming most of these problems, Alufohai (2012) identified lack of Government encouragement or incentive as one of the factors affecting adoption of BIM. As such, the author stressed the need for government involvement. Government has helped to achieve progress in most countries such as UK, USA, Singapore, Finland the use of BIM a requirement on all major projects receiving significant public funding (Onungwa and Uduma-Olugu, 2017). BIM adoption and implementation are seen to be very key and imperative to efficiency and competitiveness of the construction industry (Newton and Chileshe, 2012). Therefore, any study that facilitates its adoption will be beneficial and will lead to higher adoption rates (Banks, 2013). The current study therefore serves as a challenge for Nigeria construction professionals to developing their ability to using new and innovative technology such as BIM.

\section{Research Methodology}

This research investigated the training needs of the Nigerian construction professionals in adopting BIM. Survey research method was adopted in eliciting necessary data used for the study. Relevant information was initially obtained through a literature search and review of relevant publications. This plays a major role in the establishment of the criteria against which the empirical research were measured and in the compilation of questionnaire for the survey. The respondents for the study, were purposely, chosen from the population of selected construction professionals in Lagos State (the state is one of the most populous and economic vibrant state being considered as the major nerve centre of construction activities in Nigerian). The selected professionals are architects, quantity surveyors, structural engineers and building services engineers; who are directly involved in construction 
project activities and are found to be familiar with BIM concepts and application. The questionnaire was designed in a way to halt further response from those who are not aware of or familiar with BIM after giving their background information. In determining a suitable sample size for the selected professionals, appropriate statistic was applied on the total population obtained from the lists of registered professionals published by their respective professional bodies. Based on this, a total of 285 questionnaires were systematically administered on the respective professionals: 61 architects, 96 quantity surveyors, 61 structural engineers and 67 mechanical and electrical engineers. A total of $212(74.39 \%)$ valid responses received from 47 architects, 90 quantity surveyors, 41 structural engineers and 34 mechanical and electrical engineers, were used for the analysis. The first part of the questionnaire elicited general information about the respondents, including their preliminary knowledge about BIM. The later part concerns on issues relating to skills and facilities required for adopting and implementing BIM. The respondents' choices of answers ranged on a five-point Likert scale from "Least Favourable" to "Most Favourable". The elicited data were subjected to the Cronbach alpha reliability test. The results were greater than 0.70 of the acceptable guideline. The data were subsequently analysed using descriptive statistics such as frequency distribution, percentages and mean score. The mean value responses of common variables were further compared within the different groups of selected professionals and the associated analysis of variance (ANOVA) presented.

\section{RESULTS AND DISCUSSION OF FINDINGS}

\section{Respondents' Information}

The distribution of respondents' academic qualifications indicates that majority of the respondents (94\%) have graduate or advanced postgraduate degree certificate of the selected disciplines in the built environment. $45.3 \%$ of the respondents have work experience between five to 10 years in the construction industry, $23.1 \%$ have below five years of working experience and $31.6 \%$ have work experience over 10 years. In summary, the surveyed construction professionals are adjudged to have a good representation of their various professional bodies and a little above average reliable working experience with approximated average mean of nine years. They are therefore deemed qualified and competent to provide resourceful and reliable information for the study. The high response rate recorded may be attributable to the positive and great yarning for BIM applications among Nigerian construction professionals. This is very much in tandem with the progressive pattern in BIM awareness globally as by previous studies such as Boon and Prigg (2012) and Masterspec (2012).

\section{Skill Requirements for BIM Adoption}

The respondents were asked to indicate their perception on the skill requirement for the adoption of BIM. From the skills identified by Aftab et al. (2014) as necessary for BIM adoption, a total number of 11 required skills were adapted for the study. The results of the perceptions of the selected professionals are contained in this section. Table 4 shows the mean score ranking across the construction professionals. 
From the overall ranking, computing skill (4.47) followed by cost modelling skill (4.33), computer aided design skill (4.28), construction technology skill (4.25), coordination skill (4.23), time modelling skill (4.14) and design skill (4.08) ranked most essential skills required for the adoption of BIM concepts and applications. Virtual modelling skill (3.96), sustainability skill (3.91), building lifecycle skill (3.69) and mechanical and electrical services skill (3.50) are moderate skills required for the adoption of BIM. These skills can be acquired through undergoing relevant training on BIM concepts and applications. Acquiring training on BIM concepts involves more than just working in a digital environment.

It is also premised on ensuring that construction teams have relevant knowledge of BIM enables tools, appropriate skill requirements and facilities to enhance adopting BIM for best practice. To fully adopt BIM, professionals in the built environment are expected to show reasonable measures of awareness and training knowledge of BIM tools and dimensions available for each professional practice.

Table 4. Skills Required for the Adoption of BIM

\begin{tabular}{lcccccc}
\hline \multirow{2}{*}{$\begin{array}{l}\text { Skills Required for } \\
\text { BIM Adoption }\end{array}$} & Architects & $\begin{array}{c}\text { Quantity } \\
\text { Surveyors }\end{array}$ & $\begin{array}{c}\text { Structural } \\
\text { Engineers }\end{array}$ & $\begin{array}{c}\text { Building Services } \\
\text { Engineers }\end{array}$ & Overall & Rank \\
\cline { 2 - 7 } Computing skill & 3.98 & 4.56 & 3.24 & 4.79 & 4.47 & 1 \\
Cost modelling skill & 3.80 & 4.70 & 4.00 & 4.42 & 4.33 & 2 \\
Computer aided design skill & 4.45 & 4.00 & 4.10 & 5.00 & 4.28 & 3 \\
Construction technology skill & 4.40 & 4.26 & 4.24 & 3.96 & 4.25 & 4 \\
Coordination skill & 3.78 & 4.39 & 3.67 & 4.83 & 4.23 & 5 \\
Time modelling skill & 3.98 & 4.44 & 3.86 & 3.83 & 4.14 & 6 \\
Design skill & 4.33 & 3.64 & 4.29 & 4.79 & 4.08 & 7 \\
Virtual modelling skill & 4.15 & 3.74 & 3.95 & 4.29 & 3.96 & 8 \\
Sustainability skill & 3.90 & 4.03 & 3.38 & 3.88 & 3.91 & 9 \\
Building life cycle skill & 3.53 & 4.06 & 3.05 & 3.29 & 3.69 & 10 \\
Mechanical and electrical & 2.85 & 3.43 & 3.10 & 5.00 & 3.50 & 11 \\
services skill & & & & & \\
\hline
\end{tabular}

Moreover, Table 5 shows the result of the ANOVA test indicating the level of significant relationship between and within mean score of skills required for the adoption of BIM among the selected construction professionals.

Table 5. Analysis of Variance of Skills Required for the Adoption of BIM

\begin{tabular}{lccccc}
\hline Treatment & Sum of Squares & Df & Mean Square & F & Sig. \\
\hline Between groups & 2.564 & 3 & 0.855 & 3.808 & 0.017 \\
Within groups & 8.978 & 40 & 0.224 & & \\
\hline Total & 11.542 & 43 & & & \\
\hline
\end{tabular}


The outcome of the result shows a significant relationship between the overall mean score response with a p-value 0.017 greater than 0.005 level of significance. This implies that the respondents have similar interest in acquiring skills that will enhance the use of BIM for their professionals' practices in the construction industry. Meanwhile, the Architects required computer aided design, construction technology, design and virtual modelling skills with mean values of 4.45, 4.40, 4.33 and 4.13 respectively, as significant training needs for adopting BIM. BIM enabled cost modelling (4.70), computing (4.56), time modelling (4.44) and coordination skills (4.39) were significant training needs for Quantity Surveying practice. Meanwhile, design, construction technology and computer aided design with mean values of $4.29,4.24$ and 4.10 respectively, were significant training needs for Structural engineering practices. For building services engineers, computer aided design and mechanical and electrical services, computing and design skills were significant training needs for adopting BIM concepts and applications. These findings indicate the need to improve and increase skills/competencies of construction professionals in the operation of BIM technology and as well processes right from pre-BIM work phase to post-BIM work phase. This will create effective use of BIM concepts and applications across each phase of the construction work. In summary, the surveyed respondents poise the needs for adequate training on relevant BIM skills and competencies considered viable for their professional practice in enhancing their knowledge prowess of BIM applications and its functionality.

\section{Training Methods}

This section presents the results of the method appropriate for BIM training. The respondents were asked to indicate their perception on the identified training methods (as harmonised from the studies of Bernstein and Pittman [2011], Jupp [2015] and Oke [2016]). Table 6 presents the appropriate training methods suitable for the adoption of BIM among the selected construction professionals. Organising regular workshop on BIM software (4.59) and attending related conferences on BIM use and applications (4.48) ranked the highest of the training methods appropriate for BIM adoption. Creating on job training (4.40), project-based training (4.17), including BIM training in the firm's syllabus (4.11) and hiring a BIM specialist for staff competence (4.06) all ranked significant among training methods essential for the adoption of BIM. Inclusion of BIM education in the higher institutions' curriculum (3.97), web-based training (3.81), outsourcing BIM specialist (3.77), Iuncheon roundtables training (3.48), off job training (3.41) and formal classes (3.39) are moderately significant training methods considered by the surveyed respondents as required for the adoption of BIM.

The construction organisations or firms should adopt the use of appropriate training methods for a successful BIM adoption by investing adequately in creating enable environment to achieve this. Most appropriate training methods required by the construction professionals in adopting BIM are indicated as organising regular workshop on BIM software, attending related conferences on BIM use and applications, creating on job training, project-based training and among others and as also identified in previous study by Bernstein and Pittman (2011). Furthermore, the use of formal such as including BIM education in the higher institution's curriculum is seen to be very important. Macdonald and Mills (2011) had earlier indicated the need to establish BIM education framework to support adoption of BIM academic 
education by AEC. This will help to entrench and accommodate BIM competences for respective AEC programmes.

Table 6. Training Methods required for the Adoption of BIM

\begin{tabular}{lcc}
\hline BIM Training Methods & Mean Score & Rank \\
\hline Organising regular workshop on BIM software & 4.59 & 1 \\
Attending related conferences on BIM use & 4.48 & 2 \\
On job training & 4.40 & 3 \\
Project-based training & 4.17 & 4 \\
Including BIM training in the firm's syllabus & 4.11 & 5 \\
Hire of BIM specialist for staff competence in BIM & 4.06 & 6 \\
Including BIM education in the Higher Institution's curriculum & 3.97 & 7 \\
Web-based training & 3.81 & 8 \\
Outsourcing BIM specialist for supportive organisational structure & 3.77 & 9 \\
Luncheon roundtables training & 3.48 & 10 \\
Off job training & 3.41 & 11 \\
Formal classes & 3.39 & 12 \\
\hline
\end{tabular}

\section{Required Software for Training Construction Professionals in Adopting BIM}

This section presents the results of the software require for training construction professionals in anticipation for BIM adoption. The respondents were asked to indicate their perception on the identified software (as harmonised from the studies of Succar (2009) and Ezeabasili et al. (2015). Table 7 shows the application software required by the respective professionals. For Architectural packages, it was realised that receiving adequate training on the use of BIM enabled Revit (3.75), AutoCAD (3.53), Autodesk (3.18) and ArchiCAD (3.08) ranked moderately significant. The surveyed respondents ranked Graphisoft ArchiCAD (2.75), Autodesk Navisworks (2.55) and Bentley Arch (2.20) as less significant software packages required for training construction professionals in the adopting BIM concepts and applications.

Similarly, the surveyed respondents show a great need for adequate training on Autodesk Navisworks (4.15), Revit (4.11) and CADDUCT (4.05) as they ranked significant for engineering practice. Meanwhile, Bentley Struct (3.85), Bentley Mech (3.83), Nemetschek vector works (3.68), FireCAD (3.39) and Quality Function Deployment (3.05) ranked moderate in training requirements for the adoption of BIM for engineering practice. The surveyed respondents who are into Quantity Surveying practice, show essential training needs on the use of BIM enabled Ms Project (4.44), Cost X (4.35) and Innovaya (4.15). Meanwhile VICO (2.68) ranked less essential. For the general BIM software required for training the surveyed respondents, Bentley generative components (2.68) synchro project constructor (2.65), Solibri model checker (2.59) and Dassault systems CATIA (2.45) are considered less essential training needs of construction professionals in adopting BIM.

The findings reveal that adequate training on the use of BIM application software for every professional practice such as architectural, quantity surveying, structural and mechanical and electrical engineering practices will enhance 
knowledge acquisition and technical-know-how of BIM concepts and applications. This is key and significant to a successful adoption of BIM among construction professionals and other stakeholders in a BIM enabled environment.

Table 7. Software Required for the Adoption of BIM

\begin{tabular}{|c|c|c|}
\hline \multirow{2}{*}{ BIM Software } & \multicolumn{2}{|c|}{ Level of Training } \\
\hline & Mean Score & Rank \\
\hline \multicolumn{3}{|l|}{ Architectural Packages } \\
\hline Revit & 3.75 & 1 \\
\hline AutoCAD & 3.53 & 2 \\
\hline Autodesk & 3.18 & 3 \\
\hline ArchiCAD & 3.08 & 4 \\
\hline Graphisoft Archicad & 2.75 & 5 \\
\hline Autodesk Navisworks & 2.55 & 7 \\
\hline Bentley Arch & 2.20 & 8 \\
\hline \multicolumn{3}{|l|}{ Engineering Packages } \\
\hline Autodesk Navisworks & 4.15 & 1 \\
\hline Revit & 4.11 & 2 \\
\hline CADDUCT & 4.05 & 3 \\
\hline Bentley Struct & 3.85 & 4 \\
\hline Bentley Mech & 3.83 & 5 \\
\hline Nemetschek Vector Works & 3.68 & 6 \\
\hline FireCAD & 3.39 & 7 \\
\hline Quality Function Deployment & 3.05 & 8 \\
\hline \multicolumn{3}{|l|}{ Quantity Surveying Packages } \\
\hline MS Project & 4.44 & 1 \\
\hline Cost $X$ & 4.35 & 2 \\
\hline Innovaya & 4.15 & 3 \\
\hline $\mathrm{VICO}$ & 2.68 & 4 \\
\hline \multicolumn{3}{|l|}{ General BIM Software } \\
\hline Bentley Generative Components & 2.68 & 1 \\
\hline Synchro Project Constructor & 2.65 & 2 \\
\hline Solibri Model Checker & 2.59 & 3 \\
\hline Dassault Systems CATIA & 2.45 & 4 \\
\hline
\end{tabular}

\section{Facilities Required for BIM Training and Adoption}

For successful BIM training and eventual adoption, certain facilities are germane. Table 8 shows the facilities required for enabling BIM training among the surveyed construction professionals. Internet connectivity (4.57) ranks first, integrated computer systems (4.53) ranks second, available BIM software (4.52) ranks third, 
BIM workshop (4.49) ranks forth and availability of well-trained BIM staff or operator (4.45) ranks fifth. Powerful CPUs (4.37), BIM training package (4.36), uninterrupted power supply (4.35), large data storage device (4.29) and interoperability system component (4.11) are also ranked significant facilities required for BIM training among construction professionals/participants. Large screen monitors (3.97) and video conferencing with large display screens (3.75) ranked moderate part of the facilities required for BIM training.

Table 8. Facilities required for Training and Adoption of BIM

\begin{tabular}{lcc}
\hline Facilities Required for BIM Training & Mean Score & Rank \\
\hline Internet connectivity & 4.57 & 1 \\
Integrated computer systems & 4.53 & 2 \\
Availability of BIM software & 4.52 & 3 \\
Workshop & 4.49 & 4 \\
Availability of well-trained BIM staff or operator & 4.45 & 5 \\
Powerful CPUs & 4.37 & 6 \\
BIM training package & 4.36 & 7 \\
Uninterrupted power supply & 4.35 & 8 \\
Large data storage device & 4.29 & 9 \\
Interoperability system component & 4.11 & 10 \\
BIM business vendor & 4.10 & 11 \\
Communication devices & 4.09 & 12 \\
Large screen monitors & 3.97 & 13 \\
Video conferencing with large display screens & 3.75 & 14 \\
\hline
\end{tabular}

The results indicate capacity needs for any construction professionals' firm or organisation in preparation for training and adoption of BIM. Facilities such as internet connectivity, integrated computer systems, availability of BIM software and well-trained BIM staff or operator and organising workshop on BIM among others are salient requirements for successful training and adoption of BIM among Construction Professionals. Upgrading the firms' facilities in these regards will promote adequate knowledge acquisition among the construction professionals in the construction industry. For an adequate BIM training and adoption, firms typically require hardware and networking upgrades such as more powerful central processing units, large memory and data storage device and large screen monitors, communication devices, etc. Technology training needs for efficient BIM operations based on technology for collaboration through the use of video conferencing technology and large display screens. To enhance technology for analysis and visualisation, visualisation software is very important in design advancement. To enhance the sheer amount of information shared, a data management solution through the use of additional computing power such as cloud computing is key. 


\section{CONCLUSIONS AND RECOMMENDATIONS}

The myriad of opportunities that BIM presents to the construction industry, warrant the need for the stakeholders, especially the professionals, to be adequately trained on the use of BIM. Major BIM enabled skills, software applications, facilities and appropriate training methods were identified and assessed as necessity for the adoption of BIM concepts and applications in the construction industry. Findings from the study reveal a great need for adequate training of construction professionals on skills and competencies that that enables BIM mode of practice. This can help contribute to closing the gap that is apparent in this regard and perhaps help in resolving many of the problems bedeviling project delivery in the Nigerian constriction industry. Attainment of this feat will require a spirited effort in embracing the emerging and fast-growing concept. It is patently clear that some very relevant developments, such as BIM, will influence the future. As such, construction professionals should understand this and be prepared to participate in a pro-active manner. In bridging the training gap, professional bodies should pay attention to adopting suitable training methods such as organising regular workshop and conference on BIM concepts and application, establishment of BIM academy where professional members can enroll to acquire proper training on BIM concepts and applications. Construction organisations and firms should be well equipped with modern facilities and software packages that can enhance adequate training for successful adoption of BIM. BIM education may accelerate the process of adopting BIM and as such, education community has been examining the best ways of introducing BIM into the curricula. Due to the fact that construction stakeholders such as project managers and BIM managers may require different BIM skills in practice, understanding BIM skills could help to better formulate the education program for college students and industry professionals (Rahmana et al., 2016). As BIM continues to evolve, it is further recommended that academic programmes in institutions of higher learning be reviewed and strengthened to inculcating adequate training in BIM concepts and application. This will ensure that the the next generation of students are appropriately equipped for the future and thereby boost the chance of the industry to be BIM enabled and compliant.

\section{REFERENCES}

Abanda, F.H., Manjia, M.B., Pettang, C., Tah, J.H.M. and Nkeng, G.E. (2014). Building Information Modeling in Cameroon: Overcoming existing challenges. International Journal of 3-D Information Modeling (IJ3DIM), 3(4): 1-25. https://doi.org/10.4018/ij3dim.2014100101.

Abdirad, H. and Dossick, C.S. (2016). BIM curriculum design in architecture, engineering and construction education: A systematic review. Journal of Information Technology in Construction (ITCon), 21: 250-271.

Abubakar, M., Ibrahim, Y.M., Kado, D. and Bala, K. (2014). Contractors' perception of the factors affecting Building Information Modelling (BIM) adoption in the Nigerian construction industry. Proceedings: 2014 International Conference on Computing in Civil and Building Engineering. Virginia: American Society of Civil Engineers (ASCE). https://doi.org/10.1061/9780784413616.022. 
Aftab, H.M., Ismail, A.R., Irfana, M. and Nur, I.A. (2014). BIM in Malaysian construction industry: Status, advantages, barriers and strategies to enhance the implementation level. Research Journal of Applied Sciences, Engineering and Technology, 8(5): 606-614. https://doi.org/10.19026/rjaset.8.1012.

Alkinani, H. (2013). Models of Training Needs Assessment for the Iraqi construction industry. PhD diss. University of Salford.

Alufohai, A. (2012). Adoption of building information modelling and Nigeria's quest for project cost management. Paper presented at the FIG Working Week 2012, Knowing to Manage the Territory, Protect the Environment, Evaluate the Cultural Heritage. Rome, Italy, 6-10 May.

Au, K.M., Altman, A. and Roussel, J. (2008). Employee training needs and perceived value of training in the Pearl River Delta of China: A human capital development approach. Journal of European Industrial Trading, 32(1): 19-31. https://doi.org/10.1108/03090590810846548.

Azhar, S., Khalfan, M. and Maqsood, T. (2012). Building Information Modeling (BIM): Now and beyond. Australasian Journal of Construction Economics and Building, 12(4): 15-28. https://doi.org/10.5130/AJCEB.v12i4.3032.

Banks, D. (2013). What are the facilitating factors to the adoption of BIM in the UK quantity surveying profession? BSC diss. University of Salford.

Becerik-Gerber, B., Gerber, D.J. and Ku, K. (2011). The pace of technological innovation in architecture, engineering and construction education: Integrating recent trends into the curricula. Journal of Information Technology in Construction, 16: 411-432.

Becerik-Gerber, B., KU, K. and Jazizadeh, F. (2012). BIM-enabled virtual and collaborative construction engineering and management. Journal of Professional Issues in Engineering Education and Practice, 138(3): 234-245. https://doi.org/10.1061/(ASCE)Ei.1943-5541.0000098.

Bernstein, P.G. and Pittman, J.H. (2011). Realizing the Benefits of BIM. San Rafael, CA: Autodesk Inc. Available at: http://autodesk.com/bim [Accessed on 12 June 2017].

Boon, J. and Prigg, C. (2012). Evolution of Quantity Surveying Practice in the Use of BIM: The New Zealand Experience. Auckland: Unitec Institute of Technology.

Brummer, D.G. (2004). Challenges of quantity surveyors in South Africa: Procuring the future. In 4th World Congress of International Cost Engineering Council (ICEC). Sydney: ICEC, 21-37.

Carlisle, J., Bhanugopan, R. and Fish, A. (2011). Training needs of nurses in public hospitals in Australia: Review of current practices and future research agenda. Journal of European Industrial Training, 35(7): 687-701. https://doi. org/10.1108/03090591111160797.

Dare-Abel, O.A, Igwe, J.M. and Charles, K.A. (2014). Proficiency and capacity building of human capital in Architectural firms in Nigeria. Paper presented at the International Conference on Science, Technology, Education, Arts, Management and Social Science, iSTEAMS Research Nexus Conference. Afe Babalola University, Ado-Ekiti, Nigeria, May.

Davidson, R.D. (2013). A study of the deployment and impact of Building Information Modeling software in the construction industry. MSc diss. Leeds University.

Detsimas, N., Coffey, V., Sadiqi, Z. and Li, M. (2016). Workplace training and generic and technical skill development in the Australian construction industry. Journal of Management Development, 35(4): 486-504. https://doi.org/10.1 108/JMD05-2015-0073. 
Dim, N.V. Ezeabasili, A.C.C and Okoro, B.U. (2015). Managing the change process associated with Building Information Modelling (BIM) implementation by the public and private investors in the Nigerian building industry. Donnish Journal of Engineering and Manufacturing Technology, 2(1): 001-006.

Ede, A.N. (2014) Building information modeling: Case study of a duplex project in Nigeria. International Journal of IT, Engineering and Applied Sciences Research, 3(4): 25-28.

Enegbuma, W.I., Aliagha, G.U., Ali, K.N. and Badiru, Y.Y. (2016). confirmatory strategic information technology implementation for Building Information Modelling adoption model. Journal of Construction in Developing Countries, $21(2): 113-129$.

Fellows, R. and Liu, A.M.M. (2010). Managing organizational interfaces in engineering construction projects: Addressing fragmentation and boundary issues across multiple interfaces. Construction Management and Economics, 30(8): 653671. https://doi.org/10.1080/01446193.2012.668199.

Froise, T. (2014). Building information modeling as a catalyst for an integrated construction project delivery culture in South Africa. PhD diss. Nelson Mandela Metropolitan University.

Hardie, M., Miller, G., Manley, K. and McFallan, S. (2005). The quantity surveyor's role in innovation generation, adoption and diffusion in the Australian construction industry. Paper presented at the Queensland University of Technology (QUT) Research Week. Brisbane, Australia, 4-8 July.

Hassan, A. and Yolles, H. (2009). Building Information Modelling, a primer. Canadian Consulting Engineer, June/July: 42.

Hassan, P.F., Griffith, A. and Stephenson, A. (2005). An empirical study of the training needs of site managers within the UK construction industry. In F. Khosrowshahi (ed.), Procs. 21 st Annual Conference. Reading, UK: Association of Researchers in Construction Management (ARCOM).

Hosseini, M.R., Azari, E., Tivendale, L. and Chileshi, N. (2014). Barriers to adoption of BIM in Iran: Preliminary results. Paper presented at the 6th International Conference on Engineering, Project and Production Management (EPPM2015). Gold Coast, Australia.

Ibrahim, Y.M. and Abdullahi, M. (2016). Introduction to Building Modelling. Paper presented at the 3-Day Workshop/Annual General Meeting of the Nigerian Institute of Quantity Surveyors. Port-Harcourt, Nigeria, 8-10 November.

Ibrahim, M., Abubakar, A.M. and Osunkunle, A. (2015). Applicant of BIM towards uncommon development in the Nigerian construction industry. Proceedings of Inter-Disciplinary Academic Conference on Uncommon Development, Vol. 4, No. 3. Jos, Nigeria: University of Jos.

Jung, W. and Lee, G. (2015). The status of BIM adoption on six continents. International Scholarly and Scientific Research and Innovation, 9(5): 512-516.

Jupp, J.R. (2015). Towards a theory if BIM implementation: Understanding levels of adoption and assimilation. In RICS COBRA AUBEA 2015. Sydney: School of the Built Environment, University of Technology.

Kekana, T.G., Aigbavboa, C.O. and Thwala, W.D. (2014). Building Information Modelling (BIM): Barriers in adoption and implementation strategies in the South Africa construction industry. Paper presented at the International Conference on Emerging Trends in Computer and Image Processing (ICETCIP'2014). Pattaya, Thailand, 15-16 December. 
Kori, S.A. and Kiviniemi, A. (2015). Towards adoption of BIM in the Nigerian AEC industry: Context framing, data collection and paradigm for interpretation. Paper presented at the 9th Building Information Modeling (BIM) Academy Symposium and Job Task Analysis Review. National Institute of Building Sciences, Washington DC, 7-8 April.

Kraatz, J.A., Sanchez, A.X. and Hampson, K.D. (2014). Digital modeling, integrated project delivery and industry transformation: An Australian case study. Journal of Buildings, 4(3): 453-466. https://doi.org/10.3390/buildings4030453.

Kulasekara, G., Jayasena, H.S. and Ranadewa, K.A.T.O. (2013). Comparative effectiveness of quantity surveying in a building information modelling implementation. Paper presented at the Second World Construction Symposium 2013: Socio-Economic Sustainability in Construction. Colombo, Sri Lanka, 14-15 June.

Macdonald, J.A. and Mills, J.E. (2011). The potential of BIM to facilitate collaborative AEC education. Proceedings of the 118th ASEE Annual Conference. Vancouver: American Society of Engineering Education (ASEE).

Masterspec (2012). New Zealand National BIM 2012. Auckland: Construction Information Ltd.

McGraw Hill (2009). SmartMarket Report, The Business Value of BIM: Getting Building Information Modeling to the Bottom Line. New York: McGraw Hill Research and Analytics.

Nagalingam, G., Jayasena, H.S. and Ranadewa, K.A.T.O. (2013). Building Information Modelling and future quantity surveyor's practice in Sri Lankan construction industry. Paper presented at the Second World Construction Symposium 2013: Socio-Economic Sustainability in Construction. Colombo, Sri Lanka, 1415 June.

Newton, K. and Chileshe, N. (2012). Awareness, usage and benefits of Building Information Modeling (BIM) adoption: The case of South Australian construction organisations. In S.D. Smith (ed.), Proceedings of the 28th Annual ARCOM Conference. Edinburgh: ARCOM, 3-12.

Niraj, T. and Dan, G. (2013). Advantages and challenges of using BIM: A cost consultant's perspective. In 49th ASC Annual International Conference Proceedings. Birmingham: Birmingham City University.

Odusami, K.T., Oyediran, O.S. and Oseni, A.O. (2007). Training needs of construction site manager. Emirates Journal for Engineering Research, 12(1): 73-81.

Ogwueleka, A.C. and Ikediashi, D.I. (2017). The future of BIM technologies in Africa: Prospects and challenges. In P. WU, H. Li and X. Wang (eds.), Integrated Building Information Modelling. Sharjah, United Arab Emirates: Bentham Science Publishers, 307-314.

Oke, O. (2016). Evaluation of facilities and skills requirements among quantity surveyors for the adoption of Building Information Modelling in Lagos State. Project diss. Obafemi Awolowo University.

Oladapo, A.A. (2006). The impact of ICT on professional practice in the Nigerian construction industry. The Electronic Journal of Information Systems in Developing Countries (EJISDC), 24(1): 1-19. https://doi. org/10.1002/j.1681-4835.2006.tb00157.x.

Olugboyega, O. (2016). Examining the protocol and platforms adopted for Building Information Modelling processes by Nigerian construction professionals. Journal of System and Management Sciences, 6(4): 1-45. 
Olugboyega, O. and Aina, O.O. (2016). Analysis of Building Information Modeling usage indices and facilitators in the Nigerian construction industry. Journal of Logistics, Information and Service Sciences, 3(2): 1-36.

Ondari-Okemwa, E. (2000). Training needs of practising professional librarians in the Kenyan public university libraries: A critical analysis. Library Management, 21 (5): 257-268. https://doi.org/10.1108/01435120010324969.

Onungwa, I.O. and Uduma-Olugu, N. (2017). Building Information Modelling and collaboration in the Nigerian construction industry. Journal of Construction Business and Management, 1 (2): 1-10.

Penttila, H. (2006). Describing the changes in architectural information technology to understand design complexity and free-form architectural expression. ITcon, 11 (Special issue: The effects of CAD on building form and design quality): 395.

Peña-mora, F., Vadhavkar, S. and Aziz, Z. (2009). Technology strategies for globally dispersed construction teams. Journal of Information Technology in Construction, 14: 70-80.

Plume, J. and Mitchell, J. (2007). Collaborative design using a shared IFC building model: Learning from experience. Automation in Construction, 16(1): 28-36. https://doi.org/10.1016/j.autcon.2005.10.003.

Puolitaival, T. and Forsythe, P. (2016). Practical challenges of BIM education. Structural Survey, 34(4/5): 351-366. https://doi.org/10.1108/SS-12-2015-0053.

Rahmana, R.A., Alsafouria, S., Tanga, P. and Ayera, S.K. (2016). Comparing Building Information Modelling skills of project managers and BIM managers based on social media analysis. Procedia Engineering, 145: 812-819. https://doi. org/10.1016/j.proeng.2016.04.106.

Royal Institution of Chartered Surveyors (RICS) (2015). RICS Building Information Modelling Report. London: RICS. Available at: www.scan2bim.info/files/ rics_2011_BIM_Survey_Report.pdf.

Rogers, J., Chong, H. and Preece, C. (2015). Adoption of Building Information Modelling technology (BIM) perspectives from Malaysian engineering consulting services firms. Engineering, Construction and Architectural Management, 22(4): 424-445. https://doi.org/10.1108/ECAM-05-2014-0067.

Sheglabo, J., McGill, T. and Dixon, M. (2017). An investigation of the factors that impact the intention to adopt and use $\mathrm{mICT}$ in the Libyan construction industry. Journal of Construction in Developing Countries, 22(1): 55-74. https:// doi.org/10.21315/jcdc2017.22.1.4.

Singh, M.M., Sawhney, A. and Sharma, V. (2017). Utilising building component data from BIM for formwork planning. Construction Economics and Building, 17(4): 20-36. https://doi.org/10.5130/AJCEB.v17i4.5546.

Succar, B. (2009). Building information modelling framework: A research and delivery foundation for industry stakeholders. Automation in Construction, 18(3): 357375. https://doi.org/10.1016/j.autcon.2008.10.003.

Tomek, A. and Matejka, P. (2014). The impact of BIM on risk management as an argument for its implementation in a construction company. Procedia Engineering, 85: 501-509. https://doi.org/10.1016/j.proeng.2014.10.577.

Travaglini, A., Radujkovic, M. and Mancini, M. (2014). Building Information Modelling (BIM) and project management: A stakeholders perspective. Organization, Technology and Management in Construction, an International Journal, 6(2): 1058-1065. https://doi.org/10.5592/otmcj.2014.2.8. 
Tulenheimo, R. (2015). Challenges of implementing new technologies in the world of BIM: Case study from construction engineering industry in Finland. Procedia Economics and Finance (ELSEVIER), 21: 469-477. https://doi.org/10.1016/ S2212-5671(15)00201-4.

Underwood, J. and Ayoade, O. (2015). Current position and associated challenges of BIM education in UK higher education. BIM Academic Forum, March.

Whitlock, K., Abanda, F.H., Manjia, M.B. Pettang, C. and Nkeng, G.E. (2018). BIM for construction site logistics management. Journal of Engineering, Project and Production Management, 8(1): 47-55. https://doi.org/10.32738/ JEPPM.201801.0006.

Zhang, J., Seet, B. and Lie, T.T. (2015). Building Information Modelling for smart built environments. Journal of Buildings, 5(1): 100-115. https://doi.org/10.3390/ buildings 5010100 . 